DOI: https://doi.org/10.18309/anp.v51iesp.1520

\title{
CLARICE LISPECTOR: CEM ANOS
}

\section{CLARICE LISPECTOR: 100 YEARS}

\author{
Andréia Guerini \\ Universidade Federal de Santa Catarina/CNPq, Florianópolis, Santa Catarina, Brasil \\ andreia.guerini@gmail.com \\ Frederico Augusto Garcia Fernandes \\ Universidade Estadual de Londrina/CNPq, Londrina, Paraná, Brasil \\ fredma@uel.br
}

Embora tenha nascido na Ucrânia, Clarice Lispector se dizia "brasileira e pernambucana", pois veio para o Brasil ainda criança, tendo usado a língua portuguesa para compor os seus mais diferentes textos. Clarice Lispector afirmava que "escrever é uma maldição [...], mas uma maldição que salva. [...] É uma salvação" ("Escrever II", em Aprendendo a viver, 2004, p. 179). Talvez por isso ela tenha sido uma escritora multifacetada, pois transitou por diferentes gêneros: conto, romance, crônica, textos para crianças e ainda destacou-se como tradutora e adaptadora. E a "maldição na salvação da escrita" fez de Clarice um fenômeno literário. Suas obras têm sido reeditadas e são objeto de inúmeras interpretações críticas, sem contar as inúmeras traduções de suas obras para as mais diferentes línguas, o que nos faz afirmar que é hoje uma das escritoras brasileiras mais divulgadas e lidas no exterior. Para celebrar essa autora que em 2020 completaria 100 anos, a Revista da Associação Nacional de Pós-Graduação e Pesquisa em Letras e Linguística (ANPOLL) publica este volume contendo 10 artigos, 01 resenha e 01 entrevista. Este número especial inaugura uma série anual, idealizada e coordenada por Andréia Guerini (UFSC) e Frederico Augusto Garcia Fernandes (UEL), que visa homenagear escritores e escritoras de língua portuguesa.

Abre o volume o texto "Crônicas como memoriais: a Brasília de Clarice Lispector (e o temporário desaparecimento do invisível)", no qual Maria Caterina Pincherle aborda a relação arquitetura e literatura a partir da leitura de uma crônica de Clarice Lispector sobre Brasília, que sofreu mudanças ao ser republicada por questões ligadas à censura. Na sequência, em "Clarice Lispector e a autoria feminina: tensões literárias", Rosana Cássia dos Santos reflete sobre os desafios da autoria feminina a partir de manifestações de Clarice Lispector em cartas destinadas às suas irmãs, publicadas no livro Minhas Queridas (2007), nas quais ela expressa as dificuldades e limitações enfrentadas no início de sua trajetória literária. Em "Clarice: um estudo sobre o tempo", Luana Ferreira de Freitas e Antônio Gomes Souza Filho discutem sobre três principais características do tempo nos romances Perto do coração selvagem e Água viva. No artigo "Negação da metafísica em A paixão segundo G.H., de Clarice Lispector" Jefferson Diório do Rozário analisa $A$ paixão segundo G.H., identificando no texto elementos que configuram uma narrativa de negação da metafísica. Em "Sveglia e as paisagens suíças clariceanas", Djulia Justen apresenta um percurso pelas narrativas de Clarice Lispector através do relógio Sveglia, protagonista de "O relatório da coisa". Em "O motivo do olhar: mistérios da animalidade segundo Clarice Lispector", Priscilla de Souza Klein Gnutzmann e Rony Márcio Cardoso Ferreira abordam o conto "O búfalo", republicado por Clarice Lispector em Laços de

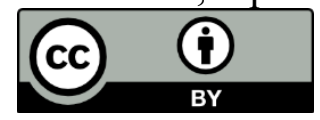


família, propondo um estudo sobre a relação do animal humano e não humano a partir das premissas teóricas dos Estudos Animais em interface com os Estudos Literários. Em "Sapatos e ritmos dos passos: notas sobre 'Preciosidade' de Clarice Lispector", Iara Pinheiro Machado propõe uma leitura do conto "Preciosidade", de Clarice Lispector, que se detém na reincidência dos sapatos como imagens de transições e mediações entre o íntimo e o externo. No artigo "O último sopro de Clarice: Um sopro de vida como Ars Poetica", Odile Cisneros trata de Um sopro de vida apresentando a problemática de sua origem e estrutura; avaliando parte de sua fortuna crítica; e sugerindo uma leitura desse texto como uma peculiar "ars poética". Em "Notas sobre Clarice Lispector e a tradução da literatura gótica anglófona", Vanessa Hanes analisa três traduções brasileiras de obras literárias góticas anglófonas feitas por Clarice Lispector. No texto "Clarice Lispector no mundo árabe: apontamentos sobre a tradução árabe de $A$ Hora da Estrela" Maged Elgebaly trata da própria experiência de traduzir para o árabe A Hora da Estrela, e da recepção da obra no Egito e nos países árabes. Na seção "Resenha", Andréia Guerini e Antônia de Jesus Sales comentam o livro A Encenação do Real: A sublimação em A paixão segundo $G$. H. e Água Viva, de Clarice Lispector, escrito por Ana Maria Agra Guimarães, e publicado pela Editora Universidade de Brasília, em 2015. Na seção "Entrevista", "Clarice Lispector na China", Li Ye entrevista Min Xuefei, a única tradutora chinesa que traduziu as obras de Clarice Lispector diretamente do português para o chinês. A sua tradução de A Hora da Estrela foi lançada em setembro de 2013 pela primeira vez e sua repercussão positiva possibilitou a republicação da tradução em 2019. Em junho de 2016 teve publicada a sua tradução de Felicidade Clandestina. Nesta entrevista, Min Xuefei fala do ato de traduzir, a aceitação e o impacto de Clarice Lispector e das obras dela no mercado chinês, com foco em aspectos da tradução literária e na divulgação de obras de Clarice Lispector na China.

Para finalizar, podemos dizer que a "maldição" da escrita não foi apenas a "salvação" de Clarice Lispector, mas também de seus leitores, críticos e tradutores. Por isso, com essas contribuições, esperamos que este número da Revista da ANPOLL venha se somar às muitas outras manifestações que estão ocorrendo ao longo deste ano no Brasil e no exterior, comprovando o vigor, a força e a potência literária das obras de Clarice, que imortalizou a língua portuguesa em seus textos. 